\title{
Equivalence class Formation Via Class-Specific Consequences in Children Diagnosed with Autism Spectrum Disorder
}

\author{
Eugênia Andréa Leão Santos ${ }^{1}$ \\ Claudia Bueno Nogueira \\ Lidianne Lins de Queiroz \\ Romariz da Silva Barros \\ Federal University of Pará, Belém, PA, Brazil \\ National Institute for Science and Technology on Behavior, Cognition, and Teaching, \\ Belém, PA, Brazil
}

\begin{abstract}
Previous equivalence-class formation studies, with class-specific consequences, found inter-subject variability, probably due to loss of efficacy of the consequences as reinforcers. This study evaluated (a) the efficacy of introducing variations of events (within a category) as class-specific consequences and (b) the inclusion of these consequences into the equivalence classes. Two children diagnosed with Autism Spectrum Disorder (ASD), and with intellectual disabilities, were given identity matchingto-sample training (Set A - Sample A1, S+A1/S-A2 and Sample A2, S+A2/S-A1) and simple discrimination reversal training (Set $\mathrm{B}-\mathrm{S}+\mathrm{B} 1 / \mathrm{S}-\mathrm{B} 2$ and reversals). Two sets of assorted videos on the same theme plus two sets of assorted food items within the same category were used as class-specific consequences. The data show that the variety of elements was efficient to maintain reinforcement efficacy and encourage the use of similar procedures in the applied context. Both participants showed strong evidence of equivalence class formation, confirming the theoretical prediction regarding the inclusion of the class-specific consequences in the classes. The data confirm that equivalence relations can be found in three-term contingencies.
\end{abstract}

Keywords: Identity matching-to-sample, simple discrimination, equivalence class formation, specific consequences, Autism Spectrum Disorder.

\section{Formação de Classes de Equivalência Via Consequências Específicas das Classes em Crianças Diagnosticadas com Transtorno do Espectro do Autismo}

\section{Resumo}

Estudos anteriores sobre a formação de classes de equivalência, com consequências específicas para as classes, apontaram variabilidade intersujeitos provavelmente devida a perda de eficácia das consequências como reforçadores. O presente estudo avaliou (a) a eficácia da introdução de variações de eventos (dentro de uma categoria) como consequências específicas das classes e (b) a inclusão de tais consequências nas classes. Duas crianças diagnosticadas com Transtorno do Espectro do Autismo (TEA), e com

Mailing address: Rua Augusto Corrêa, 01 - Campus Universitário do Guamá, Belém, PA, Brazil 66.075.110. E-mail:eugenialeao@gmail.com

Financing: Federal University of Pará, National Counsel of Technological and Scientific Development. 
deficiência intelectual, foram submetidas a treino de emparelhamento ao modelo (Conjunto A - Modelo A1, S+A1/S-A2 e Modelo A2, S+A2/S-A1) e treino de reversões de discriminações simples (Conjunto $\mathrm{B}-\mathrm{S}+\mathrm{B} 1 / \mathrm{S}-\mathrm{B} 2$ e reversões). Dois conjuntos de vídeos variados de um mesmo tema e dois conjuntos de alimentos variados dentro de uma mesma categoria foram usados como consequências específicas. Os dados mostram que a variedade de elementos foi eficiente para manter a eficácia do reforçamento e encoraja o uso de procedimentos similares em contexto aplicado. Ambos os participantes mostraram forte evidência de formação de classes de equivalência, confirmando a predição teórica sobre a inclusão de consequências específicas nas classes. Os dados confirmam que relações de equivalência podem ser encontradas em contingências de três termos.

Palavras-chave: Emparelhamento do modelo por identidade, discriminação simples, formação de classes de equivalência, consequências específicas, Transtorno do Espectro do Autismo.

\section{Formación de Clases Equivalentes a través de Consecuencias Específicas de Clase en Niños Diagnosticados con Trastorno del Espectro Autista}

\section{Resumen}

Estudios previos de formación de clases de equivalencia, con consecuencia específica de clase, encontraron variabilidad interindividual probablemente debido a la pérdida de eficacia de las consecuencias como reforzadores. Este estudio evaluó (a) la eficacia de la introducción de variaciones de eventos (dentro de una categoría) como consecuencias específicas de clase y (b) la inclusión de tales consecuencias en las clases de equivalencia. Dos niños diagnosticados con Trastorno del Espectro Autista y con discapacidad intelectual, recibieran entrenamiento de igualación de identidad a la muestra (Conjunto A - Muestra A1, S+A1/S-A1 y Muestra A2, S+A2/S-A1) y entrenamiento de inversión de la discriminación simple (Conjunto B $-\mathrm{S}+\mathrm{B} 1 / \mathrm{S}-\mathrm{B} 2$ y inversiones). Se utilizaron dos conjuntos de vídeos diversos de un mismo tema, más dos conjuntos de alimentos diversos dentro de la misma categoría como consecuencias específicas de clase. Los datos muestran que la variedad de elementos fue eficiente para mantener la eficacia del refuerzo y fomentan el uso de procedimientos similares en contexto aplicado. Ambos los participantes mostraron una fuerte evidencia de la formación de clases de equivalencia, lo que confirma la predicción teórica sobre la inclusión de las consecuencias específicas de clase en las clases de equivalencia. Los datos confirman que las relaciones de equivalencia pueden ser encontradas en las contingencias de tres términos.

Palabras clave: La identidad de la muestra, la discriminación simple, la formación de clases de equivalencia, consecuencias específicas, Trastorno del Espectro Autista.

The standard procedure to study equivalence class formation (Sidman \& Tailby, 1982) consists of training arbitrary conditional relations (through matching-to-sample procedure - MTS) and subsequent tests to verify whether these trained relations have the defining properties of equivalence relations (reflexivity, symmetry, and transitivity). Evidence of the properties mentioned above is found when new groups of conditional relations emerge. Given, for example, the training of conditional relations $\mathrm{AB}$ and
$\mathrm{BC}$, the emergence of $\mathrm{AA}, \mathrm{BB}$, and $\mathrm{CC}$ relations evidences the property of reflexivity; the emergence of the $\mathrm{BA}$ and $\mathrm{CB}$ relations evidences symmetry; and the emergency of the AC relation evidences transitivity. A forth test (CA), known as the equivalence test, combine the properties of symmetry and transitivity.

Although equivalence class formation is often found with verbally competent human participants, it has been difficult to document it in human participants with severe developmental 
delays and limited verbal repertoire (e.g. Devany, Hayes, \& Nelson, 1986), including children diagnosed with Autism Spectrum Disorder (ASD). Failures to evidence equivalence class formation in individuals diagnosed with ASD seem to be related to difficulties in reliably constructing true baseline conditional discriminations coherent with the experimental plan (Gomes, Varella, $\&$ de Souza, 2010). As a result of this, the subsequent derived relations cannot be tested.

The majority of studies successfully reporting equivalence class formation in children diagnosed with ASD also report important procedural adaptations compared to the standard procedure (McLay, Sutherland, Church, \& Tyler-Merrick, 2013). Furthermore, there is considerable inter-participant variability within and between studies. Considering that findings of equivalence class formation in the absence of sophisticated verbal repertoire (such as with low-functioning individuals diagnosed with ASD) are scarce, however, not inexistent, it is possible that part of the difficulty in documenting this phenomenon with this population is due to the inadequacy of the procedures regarding the characteristics of the participants (Barros, Galvão, Brino, Goulart, \& McIlvane, 2005).

Adaptation to the standard procedure seems to be a key issue in this topic, however, historically major changes in the standard procedure were taken as a reason to reject findings as evidence of equivalence class formation (e.g. Manabe, Kawashima, \& Staddon, 1995; McIntire, Cleary, \& Thompson, 1987; Vaughan, 1988). Alternative procedures to study equivalence class formation have become much more accepted since Sidman (2000) reviewed the original descriptive model. According to Sidman (2000), all the elements positively related in the reinforcement contingencies (including responses and consequences) may become part of the equivalence classes. Having said that, equivalence relations can be documented in identity matching-to-sample tasks (therefore with fewer stimuli involved in training than in standard procedure), or in discrimination contingences smaller than 4-terms, or can even include other elements of the contingence (such as responses and consequences).

The participation of class-specific consequences in equivalence classes had already been documented even before Sidman's (2000) publication (Dube, Mcllvane, Mackay, \& Stoddard, 1987 - see also Dube, Mcllvane, Maguire, Mackay, \& Stoddard, 1989; Schenk, 1994) and in the context of identity matching tasks (Dube \& McIlvane, 1995). Intersubject variability was always observed. For example, four out of the eight participants (children diagnosed with ASD and with severe developmental delays) did not show any evidence of class formation in Dube and Mcllvane's study (1995).

Barros, Lionello-DeNolf, Dube, and McIlvane (2006) reported equivalence class formation, with class-specific consequences, combining identity matching and simple discrimination (and reversal) tasks. The simple discrimination training consisted of two-choice discrete trials (presenting, for example, $\mathrm{S} 1$ and $\mathrm{S} 2)$. When $\mathrm{S} 1$ functioned as $\mathrm{S}+(\mathrm{S} 1+)$, selection of S1 was followed by access to the reinforcer $\mathrm{R} 1$. Once the discrimination had been learned, the contingences were reversed (S1 functioned as $\mathrm{S}-$ and $\mathrm{S} 2$ as $\mathrm{S}+$, and responses to $\mathrm{S} 2+$ produced the reinforcer R2). Discrimination reversals were conducted repeatedly (as in Vaughan, 1988). The inclusion of $S 1$ and $S 2$ in equivalence classes was successfully documented with one of the two participants (the second participant only passed in the initial tests). The authors reported evidence that the edible consequences (R1 and R2) lost efficacy as reinforcers for the participant who did not show class formation (she refused to eat the food and threw it away).

The studies mentioned above indicate that class-specific consequences can serve as nodal stimuli in the equivalence class, according to Sidman (2000), demonstrating that equivalence classes result from reinforcement contingencies. Although these studies contributed to increase the success in evidencing equivalence class relations in individuals with restricted verbal repertoire, the fact that the procedure is successful with some participants, however, unsuccessful with 
others, suggests that procedural variables may still be interfering. The refusal of the edible item selected by the participant during the research related by Barros et al. (2006) indicates loss of reinforcer value of the edibles, and suggests that it is necessary to investigate alternative procedures in this area.

The aim of the current study was to explore the efficacy of using complex reinforcers (variety of edible stimuli and videos) in procedures to evaluate the inclusion of consequences in equivalence classes for children diagnosed with ASD. This experiment also expands the study of Barros et al. (2006) investigating equivalence class formation using procedures such as identity matchingto-sample and simple discrimination. Studying reliable procedures to establish equivalence classes in children diagnosed with ASD may have a great impact on applied work, since knowledge regarding equivalence class formation may become an efficient way of constructing a complex repertoire, such as arbitrary conditional relations that are implied in the verbal repertoire, in low-functioning children diagnosed with ASD. Research on equivalence class formation with this population is justified due to its potential impact on interventions and on conceptual and methodological advances.

\section{Method}

\section{Participants}

Two boys (Henry, aged 8 years and Matthew, aged 10 years) participated in this study. They were both diagnosed with ASD and showed intellectual disabilities. Henry and Matthew received scores of 33 and 31.5 points respectively when evaluated via CARS (Childhood Autism Rating Scale - Shopler, Reichler, \& Renner, 1988). They received scores in Level 6 (auditory-visual conditional discriminations) of the ABLA Test (Assessment of Basic Learning Abilities, DeWiele, Martin, Martin, Yu, \& Thomson, 1998) and had received no formal training in equivalence class formation.
They regularly attended the Project APRENDE (Atendimento e Pesquisa sobre Aprendizagem e Desenvolvimento / Intervention and Research on Learning and Development) at the Federal University of Para (UFPA) where they received the intervention.

\section{Instruments: Experimental Environment, Apparatus, and Stimuli}

Sessions were conducted in a room measuring approximately 16 by 16 feet, specifically designed for data collection. The furniture consisted of 2 cabinets, 3 tables separated by room dividers, meeting tables and chairs. During the sessions, the participant was positioned in front of the HP All in One Touchsmart 610-110 br Computer ${ }^{\circledR}$. Two researchers sat immediately behind him (to his left and right) so they could collect data, offer praise, present edible reinforcers, and adjust the 14 megapixels video camera (which was mounted on a tripod 2 meters away and was used to record the sessions). The PCR software (Contingence of Reinforcement Program, developed by Marcio Leitão Bandeira, Paulo Roney Kilpp Goulart, Romariz da Silva Barros, and Carlos Barbosa Alves de Souza, 2009) automatically displayed the visual stimuli on the computer screen and registered the responses of the participant.

Two groups of stimuli were used during the training sessions (Group 1 and Group 2). They were non-representative black two-directional forms superimposed on $3 \times 3 \mathrm{~cm}$ white squares with a black background screen. A third group of stimuli was used during the CA relation probe: two pictures of movie characters were used as consequences.

A variety of videos of the same theme plus a variety of food items in the same category (such as sweet or savory snacks) were used as classspecific consequences. Cartoon clips, 15 -second long, were delivered via the software and edible reinforcers (sweet or savory) were dispensed by the researcher. Edible reinforcers were selected based on the results obtained in the brief MSWO reinforcement assessment (Carr, Nicolson, \& Higbee, 2000). 


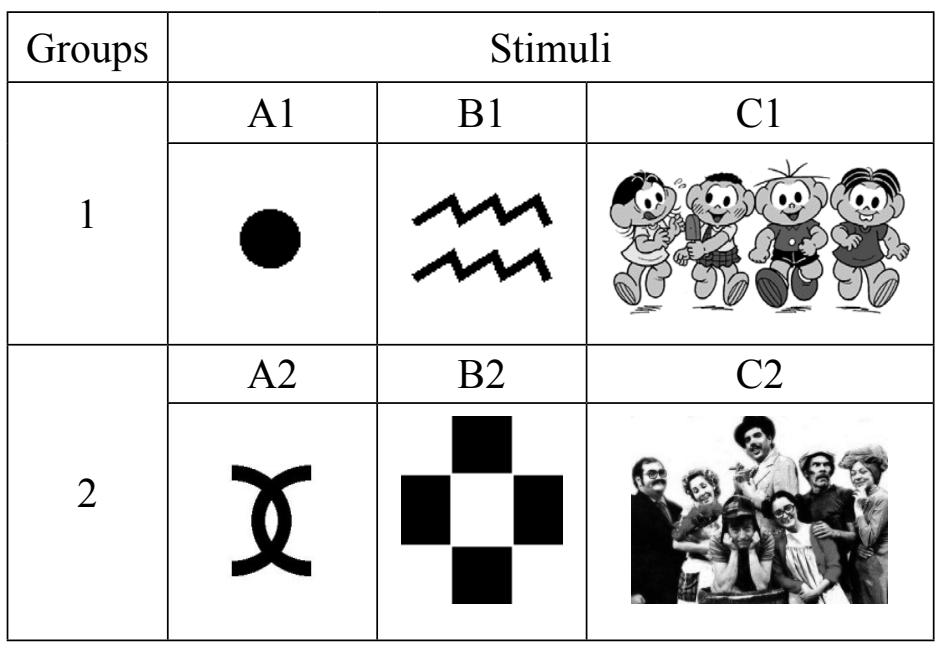

Figure 1. Sets A (A1 and A2), B (B1 and B2), and C (C1 and C2) of visual stimuli presented to the participants.

Table 1

Results from the Preference Assessment MSWO

\begin{tabular}{ccc}
\hline \multirow{2}{*}{ Participants } & \multicolumn{2}{c}{ Highly Preferred Edibles } \\
\cline { 2 - 3 } & Sweets & Salty Snacks \\
\hline Henry & M\&M's, chocolate, gummies, confeitos & Potato chips, Cheetos, torcida, skilhos \\
Matthew & M\&M's, chocolate, gummies & Potato chips, torcida, skilhos \\
\hline
\end{tabular}

\section{Data Collection Procedures}

Sessions were conducted 3 times per week and scheduled according to the participants' availability during their scheduled activities in the APRENDE program. A continuous reinforcement schedule was used during both training and testing phases, avoiding the deterioration of performance during test condition (see Galvão, Calcagno, \& Sidman, 1992). Touching the stimulus defined as $\mathrm{S}^{+}$produced: (a) the presentation of a 15 second segment of a cartoon chosen from a variety of animated video clips, (b) the presentation of edible stimuli, followed by a 1 second inter-trial-interval (ITI). Responses to the comparison stimulus defined as S- produced the removal of the stimuli for 5 seconds. Then a 1 second ITI was given and a new trial presented.

A green plastic recipient was positioned on the table to the left of the participant and a red one positioned to the right. The sweet edible stimuli were placed in the red recipient and the savory ones placed in the green recipient. There was a table with a computer next to the training/testing area. Each participant had access to computer games between session blocks of the same day and at the end of the session, regardless of the accuracy of their performance. The presence of two researchers during every session was necessary to facilitate interactions with the participant while performing computer adjustments and data collection.

Preference Assessment: Brief Multiple Stimulus without Replacement (Brief MSWO Carr et al., 2000). A preference assessment test, Brief MSWO, was conducted three times per week while the participants were attending the APRENDE program. The procedure is an adaptation of the MSWO developed by DeLeon and Iwata (1996). In the test, five items or activities are presented simultaneously. The participant chooses one item and interacts with it. Each item 
chosen is then eliminated from the next presentation and so forth, until the last item is presented. This procedure is conducted three times and the researcher records the participant's choice order. The results of the test establish a stimulus preference hierarchy.

\section{Training and Testing Procedures}

The participants were taught conditional discrimination tasks of identity and simple discrimination with visual stimuli and specific

Table 2

Summary of Training and Test Phases

\begin{tabular}{|c|c|c|c|c|c|c|c|}
\hline \multirow{2}{*}{ Phase } & \multirow{2}{*}{ Step } & \multirow{2}{*}{ Trials } & \multirow{2}{*}{ Model } & \multicolumn{2}{|c|}{ Comparison } & \multirow{2}{*}{ Conseq. } & \multirow{2}{*}{ Critéria } \\
\hline & & & & $\mathrm{S}^{+}$ & $\mathrm{S}^{-}$ & & \\
\hline \multirow{6}{*}{1} & \multirow{2}{*}{ 1.1 MTS AA } & $12 \mathrm{~A} 1 \mathrm{~A} 1$ & A1 & A1 & $\mathrm{A} 2$ & $\mathrm{C} 1$ & \multirow{6}{*}{$\begin{array}{c}90 \% \text { of correct } \\
\text { answers }\end{array}$} \\
\hline & & $12 \mathrm{~A} 2 \mathrm{~A} 2$ & $\mathrm{~A} 2$ & A2 & A1 & $\mathrm{C} 2$ & \\
\hline & 12 $\mathrm{DS} \triangle \mathrm{R} 1+$ & $12 \mathrm{~A} 1+\mathrm{A} 2-$ & - & A1 & A2 & $\mathrm{C} 1$ & \\
\hline & $1.2 \mathrm{~d} \mathrm{DS} \mathrm{AB} 1+$ & $12 \mathrm{~B} 1+\mathrm{B} 2-$ & - & B1 & B2 & $\mathrm{C} 1$ & \\
\hline & \multirow{2}{*}{ 1.2b. DS AB2+ } & $12 \mathrm{~A} 2+\mathrm{xA} 1-$ & - & A2 & $\mathrm{A} 1$ & $\mathrm{C} 2$ & \\
\hline & & $12 \mathrm{~B} 2+\mathrm{xB} 1-$ & - & B2 & B1 & $\mathrm{C} 2$ & \\
\hline \multirow{8}{*}{2} & \multirow{5}{*}{$\begin{array}{l}\text { 2.1. Test } \\
\text { MTS AB }\end{array}$} & 9 A1A1 & A1 & $\mathrm{A} 1$ & A2 & $\mathrm{C} 1$ & \multirow{8}{*}{$\begin{array}{l}\text { Correct answer } \\
\text { on first trial } \\
\text { and } 5 \text { correct } \\
\text { answers out } \\
\text { of } 6 \text { trials. }\end{array}$} \\
\hline & & $9 \mathrm{~A} 2 \mathrm{~A} 2$ & A2 & A2 & A1 & $\mathrm{C} 2$ & \\
\hline & & 3 A1B1 & A1 & B1 & B2 & $\mathrm{C} 1$ & \\
\hline & & $3 \mathrm{~A} 2 \mathrm{~B} 2$ & A2 & B2 & B1 & $\mathrm{C} 2$ & \\
\hline & & $9 \mathrm{~A} 1 \mathrm{~A} 1$ & A1 & A1 & $\mathrm{A} 2$ & $\mathrm{C} 1$ & \\
\hline & \multirow{3}{*}{$\begin{array}{l}\text { 2.2. Test } \\
\text { MTS CA }\end{array}$} & $9 \mathrm{~A} 2 \mathrm{~A} 2$ & A2 & A2 & A1 & $\mathrm{C} 2$ & \\
\hline & & $3 \mathrm{C} 1 \mathrm{~A} 1$ & $\mathrm{C} 1$ & $\mathrm{~A} 1$ & $\mathrm{~A} 2$ & $\mathrm{C} 1$ & \\
\hline & & $3 \mathrm{C} 2 \mathrm{~A} 2$ & $\mathrm{C} 2$ & $\mathrm{~A} 2$ & $\mathrm{~A} 1$ & $\mathrm{C} 2$ & \\
\hline
\end{tabular}

Each of the consequences ( $\mathrm{C} 1$ or $\mathrm{C} 2)$ included two components. Consequence 1 included one of the various videos of the same category (cartoons from the "Turma da Mônica" series) with duration of 15 seconds and one edible item from a variety of highly preferred sweet snacks. Consequence 2 included one of the various videos of the same category (clips from consequence for each potential class. Table 2 presents the sequence of training and test phases (which are described in detail below). Each block comprised 24 trials. The reinforcement contingencies with specific compound consequences (videos and edible items) were established in such a way that: (a) when stimulus $\mathrm{A} 1$ and $\mathrm{B} 1$ functioned as $\mathrm{S}+$, responding to these stimuli produced the presentation of Consequence 1 (C1); (b) when stimulus A2 and $\mathrm{B} 2$ functioned as $\mathrm{S}+$, responding to them produced Consequence $2(\mathrm{C} 2)$. 
once during a block. At least two edible stimuli for each category (sweet and savory) were presented in each 24-trial block.

A training block ended when: (a) the 24 trials concluded; (b) Six consecutive errors were registered (which might warrant changes in the procedure) or (c) after 15 minutes; whichever happened first. Each training stage ended when the participant's performance reached at least $90 \%$ accuracy in two consecutive blocks.

\section{Phase 1 - Training}

Step 1.1 - Identity matching-to-sample (MTS) AA training with specific consequences. The participants received training in two conditional relations of stimulus identity (A1-A1 and A2-A2) with specific reinforcement. Each trial started with the presentation of the sample stimulus (for example: A1). The response of touching the sample stimulus produced its removal and the immediate presentation of two comparison stimuli (A1 and A2). When the sample presented was $\mathrm{A} 1$, the response of selecting the comparison stimulus A1 was followed by the presentation of consequence $\mathrm{C} 1$, then by a 1 second inter-trialinterval (ITI). If the A2 sample was shown on the computer screen, the S+ would be the comparison stimulus $\mathrm{A} 2$ and choosing this stimulus would be followed by consequence $\mathrm{C} 2$, then by a 1 second ITI.

Step 1.2 - Simple discrimination training (Class 1) and reversal (Class 2) with classspecific consequences. The task consisted of 24 simple discrimination trials in each block. One of the following pairs of stimuli (A1-A2 or B1-B2) was presented in a random order. The response of touching any stimulus produced their removal. When the participant selected the stimulus defined by the experimenter as $\mathrm{S}+$ for that block, a 15 second duration video and an edible item were presented followed by a 1 second inter-trial interval (ITI). If the participant selected the stimulus defined as S-, a red screen was presented for 5 seconds on the computer. The mastery criterion was $90 \%$ of correct responses.

The stimuli A1 and B1 functioned as $\mathrm{S}+$ (correlated to the consequence $\mathrm{C} 1$ ) during the first step of the training (see Step 1.2a in Table
2). Subsequently, the stimuli A2 and B2 functioned as $\mathrm{S}+$ (correlated to consequence $\mathrm{C} 2-$ see Step 1.2b in Table 2).

Phase 2 - Tests

Step 2.2 - Arbitrary matching-to-sample (MTS) AB test. AB Probe in AA baseline. In this step, six probe trials of emerging $\mathrm{AB}$ (A1-B1 and A2- B2) relations (arbitrary MTS) were interspersed among 18 AA baseline trials (identity MTS, A1-A1 and A2-A2). The same specific contingencies of reinforcement were maintained, even during the probe trials.

Step 2.3 - Arbitrary MTS CA. CA probe in $A A$ baseline. The participants were given tests for the inclusion of the Consequence $\mathrm{C} 1$ and $\mathrm{C} 2$ components in the potential classes $\mathrm{A} 1 \mathrm{~B} 1$ and A2B2. In this case, a quadrant (picture) of one of the videos used as Consequence 1 was used as the $\mathrm{C} 1$ sample and another quadrant from the videos was used as Consequence 2 (C2 sample). Thus, $\mathrm{C} 1$ was a picture of one of the main characters from the cartoon "Turma da Monica", while C2 was an image of the characters of the cartoon "Chaves". Once again, there were six probe trials presented (C1A1 and $\mathrm{C} 2 \mathrm{~A} 2)$ among $18 \mathrm{AA}$ baselines trials, as described in the previous test.

\section{Data Analysis Procedures}

The experimental design was compatible with all studies reported in the literature regarding equivalence class formation, according to the standard descriptive model (Sidman, 2000; Sidman, \& Tailby, 1982): conditional baseline discriminations are trained and recombining (emergent) relations are tested. As non-representative black and white forms were presented as stimuli and their assigned sample and comparison stimuli were determined by the experimenter and evenly divided among the participants, no pre-testing was necessary. During the tests, the accuracy criterion to infer the emergence of the tested relation was: (a) correct response for the first test trial for each relation and (b) at least five correct responses out of six probe trials during the testing session. The above-mentioned item (a) was necessary in order to allow for continuous reinforcement in all testing trials, including 
the probe trials. The probability of randomly choosing $\mathrm{S}+$ in all four relations tested (A1B1, $\mathrm{A} 2 \mathrm{~B} 1, \mathrm{C} 1 \mathrm{~A} 1$, and $\mathrm{C} 2 \mathrm{~A} 2$ ) was 0.062 .

\section{Ethical Procedures}

The participation of the children in the study was explicitly authorized by their respective parents, who signed the consent form. This study was approved by the Research Ethics Committee (authorization No. 175.303 - December/14/2012 - Institute for Health Sciences of the Federal University of Pará) and fulfilled all local and international ethical requirements.

\section{Results and Discussion}

Both participants learned the discriminations quickly during the identity training sessions, as well as during the simple discrimination training (in seven trial blocks or less). They were then given probes of conditional relations $\mathrm{AB}$ and $\mathrm{CA}$. Results showing evidence of class formation for Henry and Matthew are displayed in Figure 2. The percentage of correct responses in each relation trained or probed per participant is presented. Accuracy scores for both participants were of at least $90 \%$ in every baseline identity MTS block, consistent with the previously observed generalized identity repertoire.

The participants also showed performance accuracy above $80 \%$ during simple discrimination training. They were given two blocks of simple discrimination training with the $\mathrm{A} 1$ and B1 stimuli followed by two blocks of simple discrimination reversal with the $\mathrm{A} 2$ and $\mathrm{B} 2$ stimuli.

Henry and Mathew showed 100\% accuracy during the trials probing the $\mathrm{A} 1 \mathrm{~B} 1$ and $\mathrm{A} 2 \mathrm{~B} 2$ emergent arbitrary relations, consistent with conditional control in all trials and maintenance of accuracy during the return to baseline. When the CA probes were presented, Henry showed $100 \%$ performance accuracy and Mathew showed $83.33 \%$ (five correct responses out of six trials and correct response in the first trial, achieving the accuracy criteria). These data, as with the data referring to the $\mathrm{AB}$ probes, show strong evidence of emergent conditional relations, suggesting equivalence class formation.

The criterion to consider class formation was strict, including accuracy in the first trial for each relation tested. This was necessary in order to allow for continuous reinforcement in all testing trials including the probe trials. The probability of randomly choosing $\mathrm{S}+$ during probe trials with two choices of stimuli was 0.5 . However, the probability of doing this for all four relations tested (A1B1, A2B1, C1A1, and $\mathrm{C} 2 \mathrm{~A} 2$ ) was 0.062 . Therefore, choosing $\mathrm{S}+$ stimuli in all first trials of every relation tested constituted strong evidence of class formation. Overall accuracy in the probe trials was $100 \%$ for Henry and $91.67 \%$ for Mathew (11 correct responses in 12 test trials: six $\mathrm{AB}$ relations and six AC relations).

It could be questioned whether the results mentioned above are due to learning by exclusion, since (a) there was programmed reinforcement in the probe trials and (b) a twochoice matching procedure was implemented. The term "exclusion" (Dixon, 1977) refers to one form of emergent matching of an undefined sample and undefined comparison stimuli, in an arbitrary matching-to-sample context. Typically, a baseline is first established in which reinforcement contingencies define conditional relations involving two or more sample-comparison pairs (e.g., Sample A1, S+ B1, S- B2; Sample A2, S+B2, S-B1). Subsequently, two types of test trials are introduced: (a) exclusion trials substitute the experimentally-undefined sample and comparison stimuli $(x)$ the defined ones (e.g., Sample $A x, \mathrm{~S}+B x, \mathrm{~S}-\mathrm{B} 2$ ); (b) control trials also substitute an undefined comparison stimulus $(y)$ for a defined stimulus, however, the sample is defined (e.g., Sample A2, S+ B2, S- By). The exclusion phenomenon is shown by (a) immediate, consistent selections of the undefined comparison in the former trials and (b) maintenance of the previously established sample - S+ relations (A2B2) in the latter trials - showing that the subject does not select the undefined stimuli indiscriminately. The term "learning by exclusion" was coined by McIlvane and Stoddard (1981), who emphasized the 

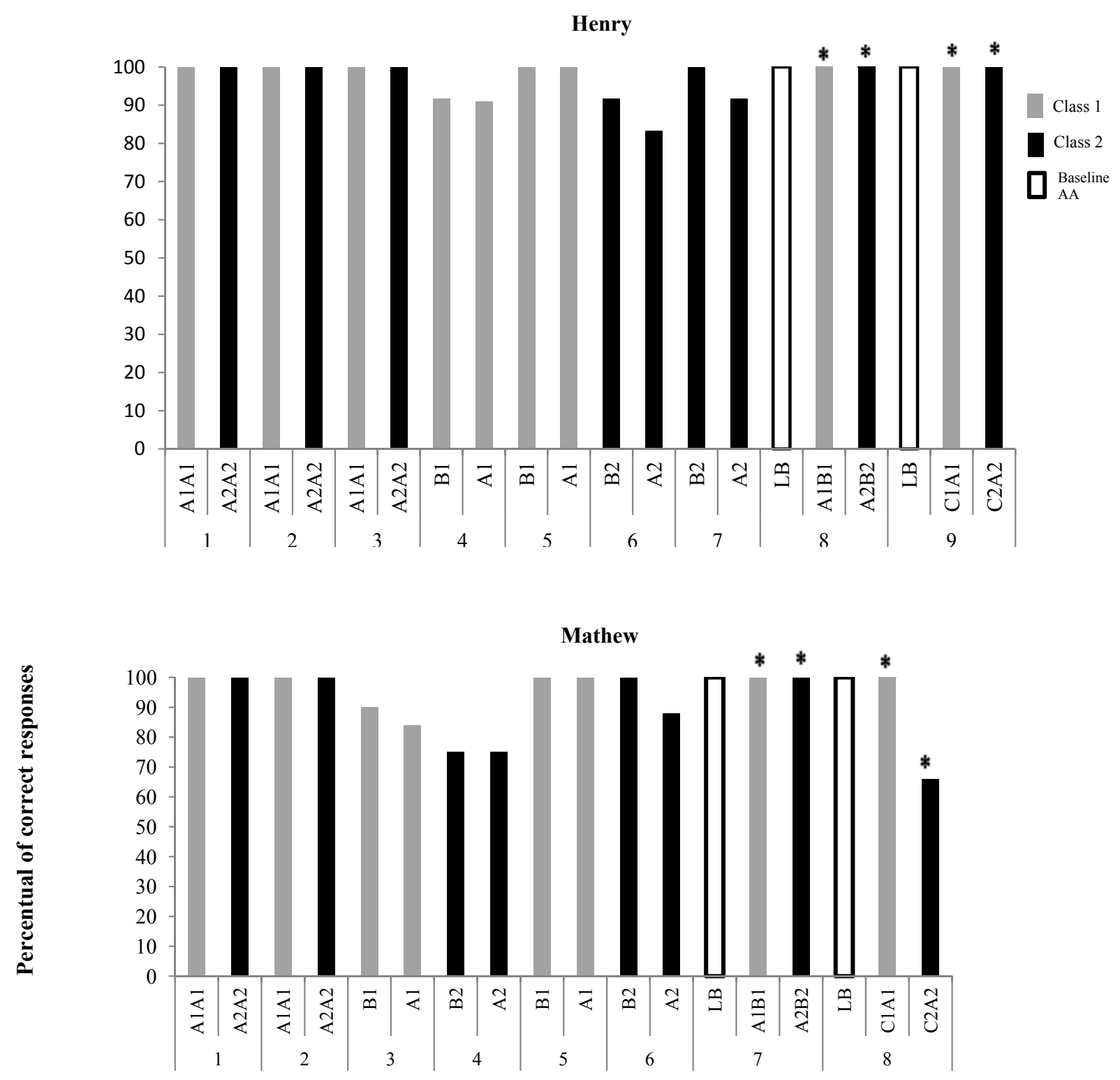

Figure 2. Participants percentual of correct responces per block, for each type of relation trained and tested. Note. *indicates probe blocks.

potential teaching advantages of the procedure. However, the explanation for the data via learning by exclusion is improbable. One would have to believe that: (a) both participants selected $\mathrm{B} 1$ by guessing in the first $\mathrm{AB}$ trial with A1 as the sample; (b) because this response is reinforced, A1-B1 would be considered a defined relation after one single trial; (c) both participants would then exclude B1 (defined stimulus) in the next $\mathrm{AB}$ probe with $\mathrm{A} 2$ as the sample. If children diagnosed with ASD showed such fast acquisition of arbitrary conditional relations, equivalence class formation would be more commonly documented in this population.
Although learning by exclusion is a highly improbable explanation for our data, it is suggested that future studies addressing the same question should program unreinforced probes, at least for the first trial of each relation tested.

The current study has conceptual, methodological, and applied implications. With respect to the conceptual implications, data found during the $\mathrm{AB}$ test probes support the theoretical predictions of Sidman (2000), according to which: (a) equivalence relations can be found in operant contingencies smaller than 4 terms, as was the case of the inclusion of Group B stimuli in the classes, after being presented 
in only 3-term contingencies and (b) specific consequences used for discrimination training can become part of the equivalence class, as nodal stimuli. The results are similar to previous findings reported in studies, with respect to difficulty in manipulating specific consequences throughout the experiment. The results found in the CA tests also confirm the participation of one component (visual stimulation provided by the pictures) of class specific consequences in the respective equivalence classes.

As another conceptual implication, the results reported here are consistent with findings reported by Barros et al. (2006) suggesting that a simple discrimination reversal procedure, usually used to study functional class formation (Vaughan, 1988), can also be useful to expand equivalence classes. These data corroborate previous findings (Kastak, Schusterman, \& Kastak, 2001; Sidman, Wynne, Maguire, \& Barnes, 1989) and suggest that equivalence classes (as defined by Sidman, 2000) and functional classes (Vaughan, 1988) are the same behavioral phenomenon accessed via different procedures.

Considering the methodological implications of the present study, findings from the probes used in this study indicate that introducing within-category variations of stimuli as specific consequences can contribute to overcoming the difficulties reported by previous studies regarding the construction of the baseline and, more specifically, the difficulty using specific consequences in equivalence class formation experiments with children diagnosed with ASD.

Concerning implications for the application of the data reported, the emergence of CA relations (with $\mathrm{C} 1$ and $\mathrm{C} 2$ functioning as discriminative stimuli after being presented only as reinforcers) should stimulate the development of equivalence-based procedures to respond to research questions originating from even more applied contexts. LeBlanc, Miguel, Cummings, Goldsmith, and Carr (2003) taught geography to children with ASD via equivalence class formation. Others (Keintz, Miguel, Kao, \& Finn, 2011) have taught relations involving the use of coins and textual control in activity schedules (Miguel, Yang, Finn, \& Ahearn, 2009). The present study, in conjunction with the studies cited above, encourages the development of procedures based on equivalence classes in the applied context, as the potential of equivalence-based teaching procedures is still underexplored.

To mention a few related examples, the inclusion of auditory class-specific consequences in equivalence classes (see Varella \& de Souza, 2014) may be an innovative and efficient way to overcome difficulties in teaching auditoryvisual discriminations in individuals diagnosed with ASD. This is particularly true if these auditory stimuli are spoken words (see Monteiro \& Barros, 2016). After visual identity matching training using class-specific spoken words as specific consequences, these auditory stimuli, once included in the equivalence classes, can be then presented as sample stimuli with the visual stimuli as comparison stimuli. Accurate responding in this new task may imply that the participants acquired some instances of listener behavior via equivalence class formation.

In order to enhance the validity of the data, future studies should feature a pre-test phase in which all the conditional relations to be eventually tested should also be previously evaluated in the absence of programmed reinforcement. This is particularly important when the conditional relations established in the context of the experiment can be seen by the participant in academic (or other) contexts (for example see, Monteiro \& Barros, 2016, who taught conditional relations between pictures of maps and corresponding flags of South American countries). Although this was not the case in the current study (since we used non-representative shapes with conditional relations assigned arbitrarily by the experimenter), by pre-testing the potentially emergent relations, the validity of the data could be enhanced.

Finally, additional studies should investigate and amplify the generality of the results reported here with children diagnosed with ASD who present a more restricted verbal repertoire, as well as with those who do not present a generalized identity repertoire. Furthermore, the stability of the equivalence classes constructed via class-specific consequences should be ex- 
amined if there is a change from class-specific to common consequences. This is particularly important as some class-specific consequences are difficult to maintain in applied settings or the natural environment.

\section{References}

Bandeira, M. L., Goulart, P. R. K., Barros, R. S., \& Souza, C. B. A. (2009). PCR: Programa de Contingências de Reforço [computer software]. Belém, PA. Universidade Federal do Pará.

Barros, R. S., Galvão, O. F., Brino, A. L., Goulart, P. R. K., \& McIlvane, W. J. (2005). Variáveis de procedimento na pesquisa sobre classes de equivalência: Contribuições para o estudo do comportamento simbólico. Revista Brasileira de Análise do Comportamento, 1(1), 15-28.

Barros, R. S., Lionello-DeNolf, K. M., Dube, W. V., \& McIlvane, W. J. (2006). A formação de classes de equivalência via pareamento por identidade e discriminação simples com consequências específicas para as classes. Revista Brasileira de Análise do Comportamento, 2(1), 79-92.

Carr, J. E., Nicholson, A. C., \& Higbee, T. S. (2000). Evaluation of a brief multiple-stimulus preference assessment in a naturalistic context. Journal of Applied Behavior Analysis, 33, 353-357.

DeLeon, I. G., \& Iwata, B. A. (1996). Evaluation of a multiple-stimulus presentation format for assessing reinforcer preferences. Journal of Applied Behavior Analysis, 29, 513-533.

Devany, J. M., Hayes, S. C., \& Nelson, R. O. (1986). Equivalence class formation in language-able and language-disabled children. Journal of the Experimental Analysis of Behavior, 46, 243-257.

DeWiele, L., Martin, G., Martin, T., Yu, C. T., \& Thomson, K. (1998). The Kerr Meyerson Assessment of Basic Learning Abilities Revised: A self-instructional manual ( $2^{\text {nd }}$ ed.).

Dixon, L. (1977). The nature of control by spoken words over visual stimulus selection. Journal of the Experimental Analysis of Behavior, 27, 433442.

Dube, W., \& McIlvane, W. (1995). Stimulus-reinforcer relations and emergent matching to sample. The Psychological Record, 45, 591-612.

Dube, W. V., McIlvane, W. J., Mackay, H. A., \& Stoddard, L. T. (1987). Stimulus class member- ship via stimulus-reinforcer relations. Journal of the Experimental Analysis of Behavior, 47, 159-175.

Dube, W. V., McIlvane, W. J., Maguire, R. A., Mackay, H. A., \& Stoddard, L. T. (1989). Stimulus class formation and stimulus-reinforcer relations. Journal of the Experimental Analysis of Behavior, 51, 65-76.

Galvão, O. F., Calcagno, S., \& Sidman, M. (1992). Testing for emergent performance in extinction. Experimental Analysis of Human Behavior Bulletin, 10, 18-20.

Gomes, C. G. S., Varella, A. A. B., \& de Souza, D. G. (2010). Equivalência de estímulos e autismo: Uma revisão de estudos empíricos. Psicologia: Teoria e Pesquisa, 26(4), 729-737.

Kastak, C. R., Schusterman, R. J., \& Kastak, D. (2001). Equivalence classification by California sea lions using class-specific reinforcers. Journal of the Experimental Analysis of Behavior, 76(2), 131-158.

Keintz, K. S., Miguel. C. F., Kao, B., \& Finn, H. E. (2011). Using stimulus equivalence to teach money skills to children with autism. Journal of Applied Behavior Analysis, 44, 909-913.

LeBlanc, L., Miguel, C. F., Cumming, A., Goldsmith, T., \& Carr, J. E. (2003). The effects of three stimulus equivalence testing conditions on emergent U. S. geography relations of children diagnosed with autism. Behavioral Interventions, 18, 279-289.

Manabe, K., Kawashima, T., \& Staddon, J. E. R. (1995). Differential vocalization in budgerigars: Towards an experimental analysis of naming. Journal of the Experimental Analysis of Behavior, 63, 111-126. doi:10.1901/jeab.1995.63-111

McIlvane, W. J., \& Stoddard, L. T. (1981). Acquisition of matching-to-sample performances in severe retardation: Learning by exclusion. Journal of Mental Deficiency Research, 25, 33-48.

McIntire, K. D., Cleary, J., \& Thompson, T. (1987). Conditional relations by monkeys: Reflexivity, symmetry, and transitivity. Journal of the Experimental Analysis of Behavior, 47, 279-285.

McLay, L. K., Sutherland, D., Church, J., \& TylerMerrick, G. (2013). The formation of equivalence classes in individuals with autism spectrum disorder: A review of the literature. Research in Autism Spectrum Disorder, 7, 418-431. 
Miguel, C. F., Yang, H. G., Finn, H. E., \& Ahearn, W. H. (2009). Establishing derived textual control in activity schedules with children with autism. Journal of Applied Behavior Analysis, 42, 703 709.

Monteiro, P. C. M., \& Barros, R. S. (2016). Emergence of auditory-visual relations viaequivalence class formation in children diagnosed with autism. The Psychological Record. doi:10.1007/s40732016-0192-1

Schenk, J. J. (1994). Emergent relations of equivalence generated by outcome-specific consequences in conditional discrimination. The Psychological Record, 44, 537-558.

Shopler, E., Reichler, R., \& Renner, B. R. (1988). The childhood autism rating scale (CARS). Los Angeles, CA: Western Psychological Services.

Sidman, M. (2000). Equivalence relations and the reinforcement contingency. Jounal of Experimental Analysis of Behavior, 74, 127-146.

Sidman, M., \& Tailby, W. (1982). Conditional discrimination vs. matching to sample: An expansion of the testing paradigm. Journal of the Experimental Analysis of Behavior, 37, 5-22.
Sidman, M., Wynne, C. K., Maguire, R. W., \& Barnes, T. (1989). Functional classes and equivalence relations. Journal of the Experimental Analysis of Behavior, 52(3), 261-174.

Varella, A. A. B., \& de Souza, D. G. (2014). Emergence of auditory-visual relations from a visual-visual baseline with auditory-specific consequences in individuals with autism. Journal of the Experimental Analysis of Behavior, 102, 139-149. doi:10.1002/jeab.93

Vaughan, W. (1988). Formation of equivalence sets in pigeons. Journal of Experimental Psychology: Animal behavior Processes, 14(1), 36-42.
Recebido: 15/05/2016

$1^{a}$ revisão; $14 / / 11 / 2016$

$2^{a}$ revisão: $22 / 11 / 2016$

$3^{a}$ revisão: $24 / 11 / 2016$

Aceite final: 24/11/2016 